$\overline{\text { 原 著 }}$

順天堂医学 $38(2)$ P. $220 \sim 228$ (1992)

\section{ラット脳ダイナミンの新しい精製法と その酵素活性及び微小管との結合様式の検討}

The new methods of purification of the rat brain dynamin and its biochemical and ultrastructural analyse of the interaction with microtubules

ダイナミンはキネシン, cytoplasmic dynein (MAP 1C) 亿次いで ATPase 活性をもち, 第 3 の微小管上のモータ一蛋白として発見された。 その後, 明らかにされた塩基配列により GP $\mathrm{T}$ 結合蛋白のコンセンサスシークエンスをもつてとがわかり, 全く新しい $\mathrm{G}$ 蛋白として注目を 集めた. 著者は新しい方法を用いて, ラット脳より高純度のダイナミンを効率良く大量に精製し， てれが今まで報告されていたダイナミンであるてとを同定した。

微小管存在下において, 微小管が存在しない場合より約 4 倍に促進される ATPase 活性 $(\mathrm{Km}$ 值 $=1.0)$ と，170倍に促進される GTPase 活性（Km 值=0.07）をもつてとを示した．さ らに急速凍結デイープエッチ法を用いてダイナミンと微小管の結合の様式を電顕にて詳細に観 察し, ダイナミンが螺旋状に微小管を装飾するてとを明らかにした。

索引用語: ダイナミン, GTP 結合蛋白, GTPase 活性, 微小管, 急速凍結デイープエッチ法

Key words : dynamin, GTP-binding proteins, GTPase activity, microtubules, quick-freeze deepetching method

\section{緒言}

細胞には細胞骨格と呼ばれる蛋白質繊維（アク チンフィラメント・微小管・中間系フィラメント) の骨組みが存在する ${ }^{11}$. その中の微小管は, 主成分 のチューブリンと微小管関連蛋白（microtubule associated proteins ; MAPs）とから構成され， 形態形式や物質の輸送に深くかかわっているとと が知られている11. 現在までにほ乳類においては, MAP 1・MAP 2 ・TAU といったフィラメント 状の MAPs に関しての研究が進められている.

\footnotetext{
* 順天堂大学医学部内科学教室腎臟内科学講座

Division of Nephrology, Department of Internal Medicine, Juntendo University School of Medicine, Tokyo, Japan

(Oct. 18, 1991 原稿受領) (Mar. 5, 1992 掲載決定)
}

これらの MAPs は, 微小管同士や微小管とニュー ロフィラメントの間に架橋構造を作っていて形態 形成に大きな役割を果たしている2) 5). 微小管は 膜小器官の輸送にとっても基本的な構造であり, そのモーターとなる分子として, ATPase 活性を もつキネシン6)・MAP 1 C (cytoplasmic dynein) が同定されてきた7).

1989年 Shpetner らが, 微小管束を形成し物質 輸送のモーターの候補と思われる第 3 の蛋白質ダ イナミンを発見した. ダイナミンは当初, 補因子 の存在下で ATPase 活性をもち, 微小管同士のス ライデイングを引き起とすととが認められた ${ }^{81}$. 最近になりラットのダイナミンの塩基配列が明ら かになり, GTP 結合蛋白に見られるコンセンサ スシークエンスを有するととがわかった ${ }^{910)}$. 更 にこのダイナミンの遺伝子がマウス $\mathrm{Mxl}$ 遺伝子 (インフルエンザウイルスの感染防御機構を担う 
蛋白を発現) ${ }^{11}$ や, 酵母 VPS 1 遺伝子 (液胞蛋白の ソーティングを司る遺伝子 ${ }^{12) 13}$ などに比較的高い 相同性をもつてとがわかった. 最近, ショウショ ウバエの温度感受性変異株におけるエンドサイトー シス機構に深くかかわっている遺伝子産物も, こ のダイナミンに高い相同性をもつととがわかり ${ }^{14 / 151}$, てれまで知られていない新しい GTP 結合蛋白の ファミリーを形成するととが示唆された。

しかし, これまでの精製方法では極少量のダイ ナミンしか得ることができなかったため, その生 化学的な蛋白の性質やGTPase としての性質は全 く調べられていなかった. 今回, 著者はダイナ之 ンの新しい精製方法を確立し, ラット脳より大量 のダイナミンをその生物的活性を損なうことなく 分離精製するてとに成功した，そしててれが今ま でに報告されているダイナミンと同一のものであ り, 微小管存在下で促進される GTPase 活性・A TPase活性をもつてとを確認した.さらにin vitro で微小管と結合させ, 急速凍結デイープエッチン グ法の手技を用いて電顕的に観察した。

\section{実験材料と実験方法}

\section{1. ダイナミンの精製}

20匹のラット (Wistar 5 週齢) の脳 $(20 g)$ に ${ }^{\circ} \mathrm{C} 30 \mathrm{ml}$ のA液〔 $10 \mathrm{mM}$ リン酸ナトリウム $(\mathrm{pH}$ $6.9) \cdot 70 \mathrm{mM}$ グルタミン酸ナトリウム・ $2 \mathrm{mM}$ $\mathrm{MgSO}_{4} \cdot 2 \mathrm{mM}$ EGTA $\cdot 1 \mathrm{mM} \mathrm{PMSF} \cdot 10 \mu \mathrm{g} /$ $m l$ leupeptin $1 \mu \mathrm{g} / m l$ pepstatin A $\cdot 1 \mathrm{mM}$ DTT】を加えたものでホモジェナイズを行う. 12,000 $g, 4{ }^{\circ} \mathrm{C} 10$ 分間の遠心を行い, その上澄みをさら に300,000g $4{ }^{\circ} \mathrm{C}$ で45分間遠心する. 得られた粗 抽出液 $\left(\mathrm{S}_{1}\right)$ をあらかじめA液で平衡化してある DEAE-セファロースカラム (DE-52 Whatmann) にかけ，通り抜け分画 ( $\mathrm{S}_{1}{ }^{\prime}$ ) を集めた. ブタ脳よ り調整したPCチュブリン $10 \mathrm{mg}$ に $20 \mu \mathrm{M}$ にな るように taxol を加えて $37^{\circ} \mathrm{C} 30$ 分加温し微小管 を重合させる.これに通り抜け分画を加えて室温 にて15分間緩やかに攪汼したのち，20\%ショ糖を 加えたA液の上に重層し, $200,000 \mathrm{~g} 4{ }^{\circ} \mathrm{C} 30$ 分間
遠心して沈澱を得る. この沈澱を2.5mM GTP • $5 \mathrm{mM}$ AMP-PNP を加えた $800 \mu l$ のA液にて懸 濁させ, $37^{\circ} \mathrm{C}$ の恒温槽にて 15 分間加温する. 再び $100,000 \mathrm{~g} 4{ }^{\circ} \mathrm{C} 30$ 分間の遠心を行い, 得られた沈 澱を $800 \mu l$ の $10 \mathrm{mM}$ GTP を加えたA液にて懸 濁し, $37^{\circ} \mathrm{C} 20$ 分間加温, $100,000 \mathrm{~g} 4{ }^{\circ} \mathrm{C} 30$ 分間遠 心して上澄 $\left(\mathrm{S}_{2}\right)$ を得る。この上澄からチュブリ ンを除くために再びA液で平衡化した DE-52カラ ムを通し, 通り抜け分画を集める $\left(\mathrm{S}_{2}{ }^{\prime}\right)$. 乙の時 点ですでにダイナミンはかなり高い純度をもつが, さらに純度を上げるために $5 \%$ ～20\%ショ糖 B 液 $\lceil 10 \mathrm{mM}$ Tris-HCI ( $\mathrm{pH} 7.0) ・ 30 \mathrm{mM}$ グルタミン酸 ナトリウム・ $2 \mathrm{mM} \mathrm{EGTA・} 2 \mathrm{mM} \mathrm{MgSO}_{4}$ 】 t 用いて, ショ糖密度勾配遠心を $30,000 \mathrm{rpm} 4{ }^{\circ} \mathrm{C} 20$ 時間の条件の下で行い, 各分画を集めた。

2.イムノブロッティング

われわれは Vallee らの方法でダイナミンを精 製し, その部分アミノ酸配列を決定し,すでにダ イナミン遺伝子をクローニングしている ${ }^{10)}$. これ はObar らの発表したダイナミン遺伝子と一致 した ${ }^{9}$. この部分アミノ酸配列をもとに合成ペプ チドを作りウサギに免疫をし, ポリクローン抗体 を作成した. この抗体を用いて得られた蛋白がダ イナミンであることを確認するために, Towbin ら（1979）の方法 ${ }^{16)}$ でウェスタンブロットを施行 した. Laemmli（1970）の方法17)で, SDS-PAGE を行ったあとのアクリルアミドゲルを PVDF 膜 にトランスファー（120mA 3 時間）し，1 次抗体 にウサギに作らせた抗ダイナミン抗体・2 次抗体 に抗ウサギ IgG を反応させた。

3. ATPase 活性・GTPase 活性の測定

$90 \mu l$ の試料（B液） $そ 10 \mu l$ の $10 \mathrm{mM}$ ATP ( $\gamma{ }^{-32} \mathrm{P}$ ATP) を水上で加え $25^{\circ} \mathrm{C}$ で反応を開始し, 60分間放置後 $10 \mu l \quad 10 \%$ SDS を加えて反応を停止 させた. 遊離してきたリン酸は ${ }^{32} \mathrm{P}-\mathrm{ATP}$ と区別す るため, $100 \mu l$ のリン酸試薬 $\left(10 \mathrm{NH}_{2} \mathrm{SO}_{4} ; 10 \%\right.$ モリブデン酸アンモニウム； $0.1 \mathrm{M}$ けいタング ステン酸 $=2: 2: 1 ）$ を加えてリンモりブデン酸 複合体を形成させた. 反応液に $1 m l$ のキシレン; イソブタノール混合液 $(65: 35 \mathrm{v} / \mathrm{v})$ を加え 20 
～30秒振とう後, $1000 \mathrm{rpm} 1$ 分間遠心して有機層 を500 $\mu l$ とり, 液体シンチレーションカウンター で32P を測定した. GTPase 活性についても同様 に測定した. Km の測定については, 加える ATP・ GTP の濃度を変えて同様の反応を10分間行い, 遊離したリン酸を測定した。

4. ダイナミンと微小管の結合

$100 \mu g / m l$ のダイナミン $300 \mu l$ と $20 \mu \mathrm{M}$ taxol にてあらかじめ $37^{\circ} \mathrm{C} 30$ 分間重合させた $500 \mu \mathrm{g} /$ $m l$ のチュブリンを $30 \mu l$ 加えて室温で10分間放 置した。

5. ネガテイブ染色

上記のダイナミンと微小管を室温で10分間おい た後に，1\%酢酸ウラン（30秒間）でネガテイブ 染色を行い電顕にて観察した。

5. 急速凍結デイープエッチング

ダイナミンと微小管とを in vitro で結合させ （上記条件）たものを $100,000 \mathrm{~g} 20^{\circ} \mathrm{C} て ゙ 30$ 分間の遠 心を行い, その沈澱を試料とした.アルミニウム デイスクの上にクッションの役割を果たすホルマ リン固定したラットの肺切片をのせ，そのうえに 試料をのせる. 試料上の余剰な水分はできるだけ 吸い取っておく, 表面を金属磨きで鏡面仕上げを した純銅ブロックを, 急速凍結装置に装着し液体 ヘリウムで急冷する. 銅ブロックの温度が平衡状 態になった時点で, 純銅ブロック表面に試料を圧 着させ急速凍結させる. 凍結試料を凍結破断装置 （Balzars BAF 400）にセットし高真空下に超低 温 $\left(-196^{\circ} \mathrm{C}\right)$ で凍結割断し, その後 $-95^{\circ} \mathrm{C}$ にまで 温度を上昇させ 7 分間エッチングを行う. 試料を 回転（ $2 \sim 3$ 回/秒）させながら白金と炭素で蒸 着させレプリカを作る. 試料をクロム硫酸に一晚 浸し肺や試料を溶かし、レプリカのみにして100メッ シュのグリッドに拾い, 透過型電顕（JEOL 1200 EX)にて観察した ${ }^{1819) .}$

\section{結果}

\section{1.ダイナミン精製}

ラット20匹の脳から得られる粗抽出液 $\left(S_{1}\right)$
は約 $18 m l$ とれ, DE-52の通り抜け分画（ $\mathrm{S}_{1}$ ' ; 図1-A lane 1）20ml を得ることができる. 表- 1 に 精製の各段階における蛋白濃度・ダイナミン濃度

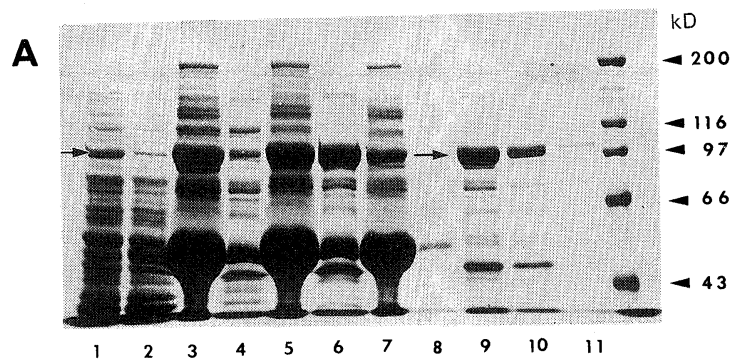

B

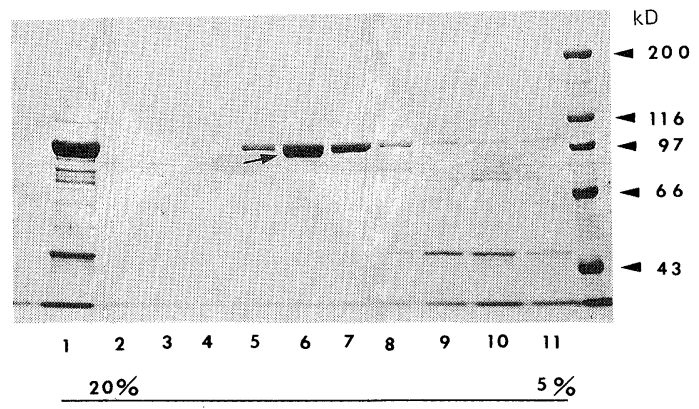

図-1 ダイナミン精製過程に扔ける SDS ポリアクリ ルアミド電気泳動

(A)；粗抽出液〜 $\mathrm{S}_{2}{ }^{\prime}$ 分画. lane 1 ：通り拔け分画. lane 2,3： 通り抜け分画にチュブリンを加光遠心後の上澄み (2), 沈澱 (3). lane 4,5：AMP-PNP，GTP 使用に よるステップの上澄み (4), 沈澱（5). lane 6,7：GTP 使用によるステップの上澄み (6), 沈澱 (7). lane 8-11：lane 6 在 DE-52にかけ, 集められた 分画

(B ) ； $5 \%$ 20\% ショ糖密度勾配遠心法の各分画.

濃縮ゲル： $4 \%$, 展開ゲル : $7.5 \%$

表- 1 ダイナミン精製各過程における蛋白濃度

\begin{tabular}{l|c|c|c|c}
\hline 過程 & 容量 $(m \ell)$ & 蛋白濃度 $(m g / m \ell)$ & 総蛋白量 $(m g)$ & \%ダイナミン \\
\hline $\mathrm{S}_{1}$ & 18 & 8.62 & 155.15 & 3.4 \\
$\mathrm{~S}_{1}$, & 20 & 4.03 & 88.66 & 7.4 \\
$\mathrm{~S}_{2}$ & 0.8 & 2.2 & 1.76 & 44.8 \\
$\mathrm{~S}_{2}$, & 1.5 & 1.01 & 1.51 & 56.1 \\
$\mathrm{SDGC}$ & 2.4 & 0.20 & 0.48 & 97.6 \\
\hline
\end{tabular}

SDGC : ショ糖密度勾配遠心分画 
を示した. また図-1 では各段階の SDS-ポリアク リルアミド電気泳動を示した. 陰イオン交換カラ ムである DE-52を通すてとによって高分子 MAPs を含む大部分の蛋白が除去され，すでにダイナミ ンのバンドが同定される（図-1-A lane 1 矢印). 集められた通り抜け分画は, チュブリンも DE-52 に吸着し内在性のチュブリンが欠如している。 そ のため, 外から taxol で重合させたブタ脳のチュ ブリンを通り抜け分画に加え, ダイナミンと結合 させ沈澱を形成させた。

ての時点で100kDのダイナミンは, チュブリン と共沈する蛋白の中で最も多いものとなっている （図-1-A lane 3 ). この沈澱からダイナミンを
$5 \mathrm{mM}$ AMP-PNP・2.5mM GTP を用い懸濁さ せ遠心後, 得られた沈澱を $10 \mathrm{mM}$ GTP にて抽出 した（この 2 回のステップ中でのそれぞれの上澄 みと沈澱の電気泳動が, 図-1-A lane-4,5,6,7 に 相当する). 抽出された $\mathrm{S}_{2}$ (図-1-A lane 6) か らあとで加えたチュブリンを除くために，2回目 の DE-52を通して $\mathrm{S}_{2}$ 'を得た（図-1-A lane 9 ・ 図-1-B lane 1). $\mathrm{S}_{2}^{\prime}$ の時点で総蛋白量のほほ56 \%にまでダイナミンが精製された。しかし, 少量 混在する $120 \mathrm{kD}$ キネシン・ $70 \mathrm{kD}$ 蛋白・ $48 \mathrm{kD}$ 蛋 白を除き,より高い純度のダイナミンを得るため に $\mathrm{S}_{2}$ 'を次のステップである $5 \%$ \% 20\%ショ糖 密度勾配遠心にかけた，その各分画の SDS-PAGE

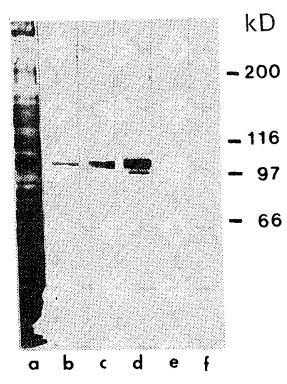

図-2：ダイナ之ンの同定

(A) ; 抗ダイナミン抗体によるウエスタンブロッテイング, lane;a,b,e $=\mathrm{S}_{1}{ }^{\prime}$, lane;c,, $\mathrm{f}=$ =精製ダイナ之ン,

CBB 染色 $=$ lane a,c,

1 次抗体に抗ダイナ之ン抗体を使用 = lane b,d,

1 次抗体に抗ウサギ IgG t使用=lane e,f,

（B）；ネガテイブ染色によるダイナミンと微小管との結合

Bar : $100 \mathrm{~nm}$

B 1

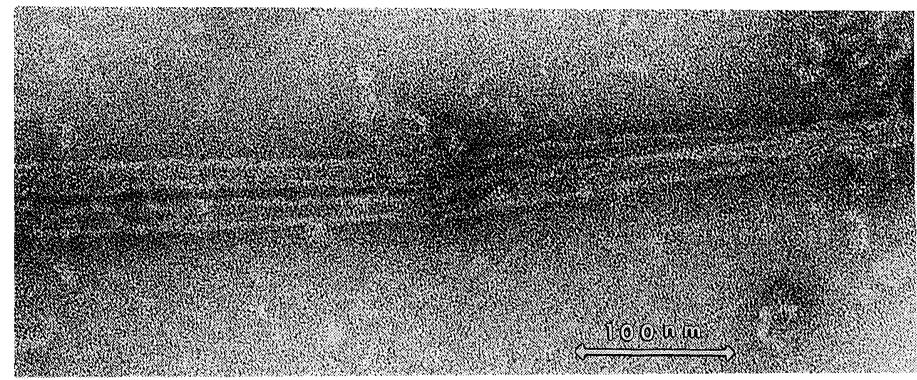

2

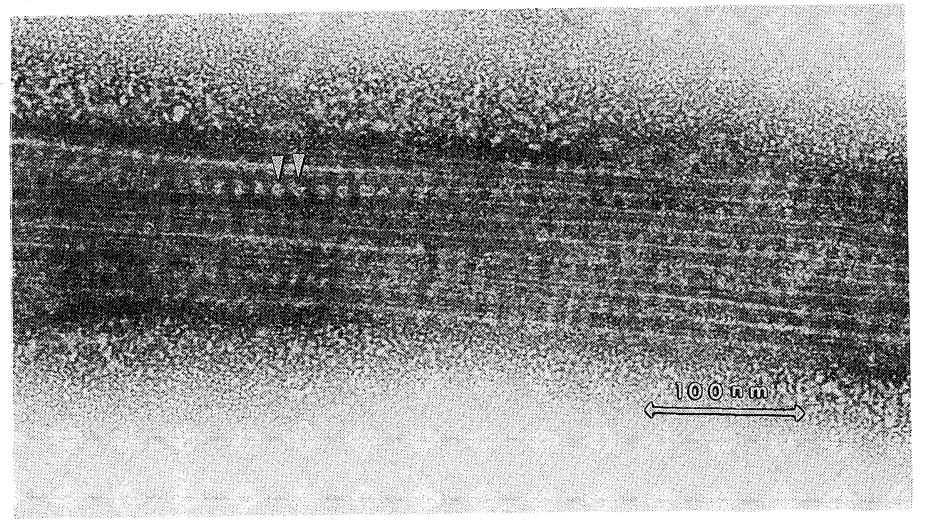


が図-1-Bであり，こてで97.6\%の高い純度のダイ ナミンを得ることができた（図-1-B lane 6). 表1 亿示したとおり, $20 \mathrm{~g}$ のラット脳より $0.4 \mu \mathrm{g}$ の ダイナミンを分離精製することができた。

2. ダイナミンの同定

1) イムノブロッテイング

今回精製したダイナミンが, Shpetner（1989） らの報告したダイナミンと同一のものであること を示すため, われわれの作成したウサギ抗ダイナ ミン抗体をもちいてウエスタンブロッティングを 行った. この抗体は, われわれや Obar らの報告 したダイナミンのアミノ酸配列をもとに合成ペプ チドに対する抗体で, 脳の粗抽出液中で特異的に ダイナミンを検出することをすでに確かめてあ $3^{10)}$. 図-2-A 亿示すように, 得られた蛋白は抗ダ イナミン抗体にてはっきりと染色された。

2 ）ダイナミンによる微小管の束化 (bundling) の電顕的観察

ダイナミンが微小管の束化をする能力をもつか を, ネガテイブ染色法を用いて電顕的に観察した (図-2-B-1,2). 図-2-B-1には，ダイナ之ンを加えて いない微小管のみのネガテイブ染色を示した.ダ イナミンを微小管に加えると微小管は著明な束を 形成し, ダイナミンは非常に規則正しくチュブリ ンに結合し（間隔 $11 \mathrm{~nm}$ )，微小管の周囲をきれい に取り囲んでいる様子が観察された. 微小管と微 小管との距離は12nm であった。

3 ) ATP-ase 活性・GTP-ase 活性の測定

ダイナミンの最大の特長のひとつでもある AT Pase 活性・GTPase 活性についても検討を行っ た. その結果を表- 2 亿示す. 微小管が存在しない 状態での ATPase 活性・GPTase 活性は，それ ぞれ $5.3 \pm 1.5 n$ moles $/ \mathrm{min} / m g, 1.6 \pm 0.8 n$ moles $/ \mathrm{min} / m g$ である. 一方, 微小管が存在す る状態ではそれぞれ20.6土4.5n moles / min / $m g \cdot 275.5 \pm 53.5 n$ moles $/ \mathrm{min} / m g$ となった。 微小管存在下でATPase 活性は約 4 倍に, GPTase 活性は約 170 倍に促進された。

以上の結果より, 今回精製した $100 \mathrm{kD}$ 蛋白はヌ クレオチド依存性に微小管を束化する能力をもち,
表- 2 ダイナミンの ATPase 活性・GTPase 活性の 比較

\begin{tabular}{|c|c|c|}
\hline & ATPase活性 & GTPase活性 \\
\hline & & \\
微小管 $(-)$ & $5.3 \pm 1.5$ & $1.6 \pm 0.8$ \\
\hline & & \\
微小管 $(+)$ & $20.6 \pm 4.5$ & $275.5 \pm 53.5$ \\
\hline
\end{tabular}

( $\mathrm{n} \mathrm{moles} / \mathrm{min} / \mathrm{mg}$ )

ダイナミンの部分アミノ酸配列に対する抗体と反 応することから, ラット脳ダイナミンであること が同定された.さらにこの方法で精製したダイナ えンは, 微小管の存在下にて強く活性化される G PTase 活性・ATPase 活性を保持することが分 かった.

\section{3 . ダイナミンの性質の検討}

1) $\mathrm{Km}$ 值

実験方法で述べたような ${ }^{32} \mathrm{P}$ の測定系を用いて， 基質として加える ATP・GTP の濃度を変えて10 分間の反応時間でデータをとった. 図-3-A に AT Pase 活性, 図-3-C に GPTase 活性を示し, 各々 の逆数をプロットし（図-3-B,D, ) Km 值をグラ フ上より求めた. ATPase ・ GPTase の $\mathrm{Km}$ 值は それぞれ $1.0 \cdot 0.07$ となった。

2 ）微小管との結合

ネガティブ染色において, 確認した微小管とダ イナミンとの結合の様式を更に詳しく観察するた めに, 急速凍結デイープエッチング法にて試料を 観察した（図-4-A,B, ). 図-4-A はチュブリンのみ の急速凍結像, 図-4-B にはダイナミンとチュブリ ンを結合させた急速凍結像を示す. ダイナミンは 微小管に対して規則正しくネガティブ染色と対応 する約 $11 \mathrm{~nm}$ の間隔をもって結合している. 微小 管に対して縄を巻いたように螺旋状に装飾してい るように観察された。 

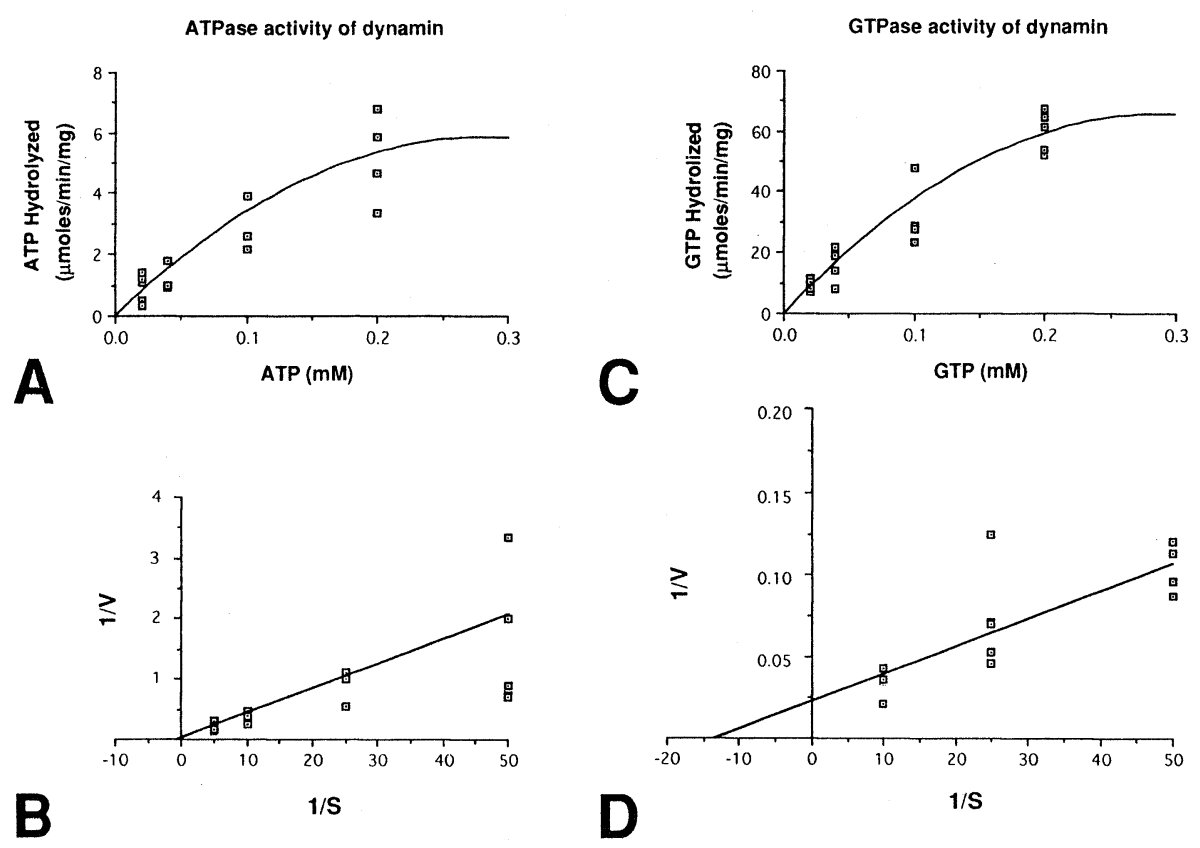

B

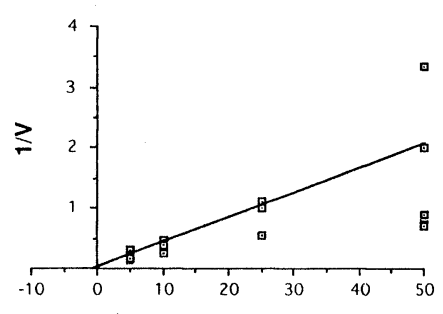

図-3 ダイナミンの ATPase 活性と GTPase 活性

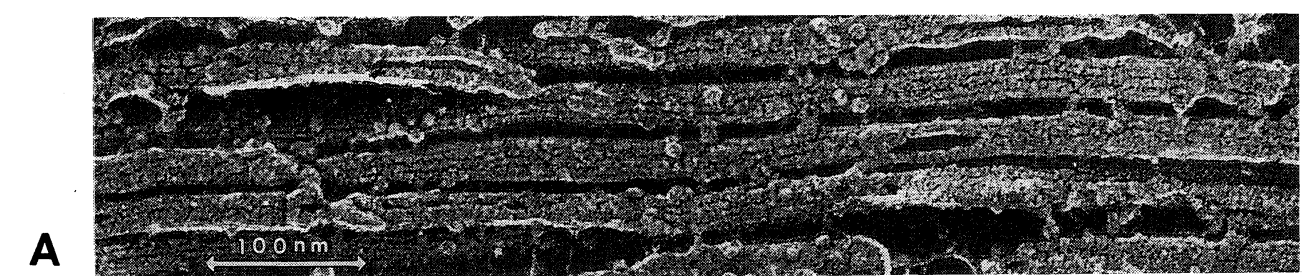

A

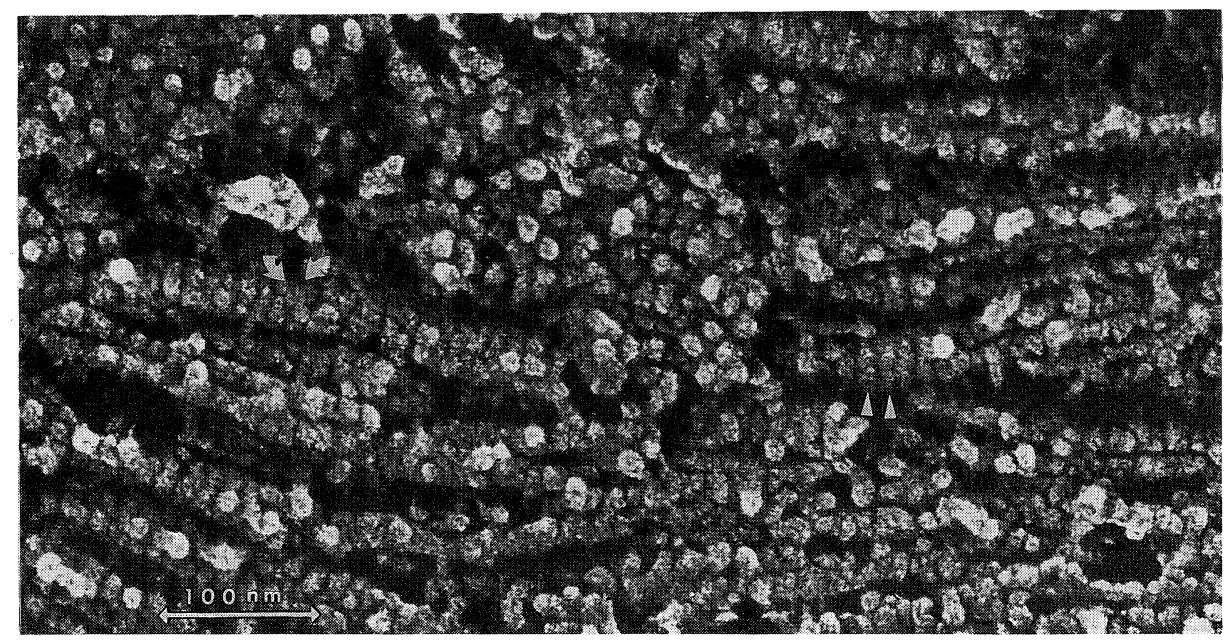

図-4 急速凍結ディープエッチング法によるダイナミンと微小管との結合Ｂar：100nm 


\section{考察}

1989年 Shpetner によって初めて報告されたダ イナミンは ATPase 活性をもち, 今までに知られ ている MAP 1C・キネシンなどとともに, 第 3 の モータ一蛋白として注目を集めた。彼らは仔牛の 脳を材料として精製しているが，日本ではなかな か材料を良い条件で実験に用いることが難しい. また, 大量の taxol を必要としなければならない という久点があった。ささら収量も少なかった。 著者はラットの脳を用い, しかも今までと全く違 う方法で効率良く, 大量にダイナミンを精製する ことに成功した. ての方法で得られた $100 \mathrm{kD}$ 蛋白 は, 既にクローニングされたダイナミンの部分ア 之八酸配列をもとにして, われわれが生成した抗 ダイナミン抗体に特異的に反応し, in vitro での 微小管束化能力を有しているととより, Shpetner らの発見したダイナ之ンそのものであるととを確 認した.

この方法は, 従来の方法に比べて以下の点で優 れている. (1) taxol を殆ど使わない. (2)大量のダ イナミンが非常に簡単に効率的に取れる. (3) Shpetner (1989) やScaife (1990) ら 201 の方法より も簡単で, しかも少ない taxol 使用量でよい. (4) 大量に取れてくるために，さらなる精製を用いて 微量に混在している他の蛋白をほとんど除くこと ができた. (5)精製の過程においてダイナ之ンの生 物的活性を損わない. ダイナミンは微小管の存在 によって促進される ATPase 活性をもっている ことが言われている. ATPase 活性は微小管の存 在により 4 倍に促進された. しかし, その 1 次構造 から GTP 結合蛋白のコンセンサスシークエンス をもっているととが分かり, GTPase 活性をもつ 可能性が示唆されていた. そこで GTPase 活性を 測定した. 微小管の存在により GTPase 活性は170 倍に促進された. その $\mathrm{Km}$ 值は ATP の場合に比 べて1／14倍と小さく, 生体内の ATP と GTP の 存在の割合を考慮（ATP：GTP=10：1）して みても, ATP より GTP のほうがより良い基質と なっていることが分かった. このことは, ダイナ
ミンが GTPase としての性質をもっていること を蛋白レベルで初めて明らかにした.GTP 結合 蛋白としても, このように微小管の存在下で強く 活性化されるものは乙れまでに報告がなく, 極め て注目に値する.さらにての GTP 結合蛋白とし ての性質や特徵を, 詳しく調べるために現在実験 を行っている.

ダイナミンは微小管と結合し束化を促すが，乙 れまでネガテイブ染色や通常の超薄切片法により， クロスブリッジ様の構造をダイナミンがとると思 われてきだ'. 今回, 分子や分子間の結合の 3 次元 構築を見るのに現在最も適した方法である ${ }^{18) 19)}$ 急 速凍結ディープエッチング法を用いて, ダイナ之 ンと微小管との結合の様子をより詳細に観察した. その結果, in vitro においてダイナミンは, 微小 管に対し縄目状に規則的かつ密に結合し，てれま での方法から考えられていたクロスブリッジ様の ダイナミンの構造の予想が全く違っていたてとが 明らかになった。 今後, ダイナミンの微小管への 結合様式について, 他の MAPs との相互作用や 結合部位の同定などの検討が必要であり, 現在そ の解明のために実験を継続している. また, ダィ ナミンの単分子の形態をも併せて観察を試みてい る.

ダイナミンは全く新しい $\mathrm{G}$ 蛋白であり, その機 能の解明が期待される. 今回著者の開発した新し い精製方法により大量のダイナミンが高純度でと れ, 今後のこの分野の研究に大きく貢献すると考 える。

\section{結語}

1. ラット脳より新しい方法を用いてダイナミン を效率良く極めて高い純度で取ることに成功した。 2 . 得られたダイナミンは, 今まで報告されてい たダイナミンの抗体と特異的に反応し, 同一のも のと思われた。

3. 得られたダイナミンは, in vitro で微小管を 束化させる能力をもっている.

4. 得られたダイナミンは, 微小管存在下で促進 
されるATPase活性・GTPase活性をもっている.

5.GTP のほうが ATP よりダイナミンにとっ てより良い基質であり,クローニングより得られ た GTP 結合蛋白にみられるコンセンサスシーク エンスを保有する事実と一致し，生体内では GT Pase として働いていると考えられる.

6.ダイナえンは微小管にたいして表面を装飾す るように縄状に結合している。

稿を終えるにあたりで㸸篤なで指導を賜った廣川信 隆東京大学医学部解剖学教授, 中田隆夫同助手, および で校閲を頂いた小出輝順天堂大学腎臓内科教授に深く感 謝すると共に, 教室の諸兄に心からお礼申し上げます。

\section{文献}

1) Hirokawa, N.,: Molecular architecture and dynamics of the neuronal cytoskelton. In the Neuronal Cytoskelton. Weilly-Liss Inc. , 5 74, 1991

2 ) Hirokawa, N., Bloom. G.S., Vallee. R.B.,: Cytoskeletal architecture and immunocytochemical localization of microtubule-associated proteins in regions of axons associated with rapid axonal transport. J. Cell. Biol., $101: 227$ $\sim 239,1985$

3 ) Sato, Y.R., Hirokawa, N.: Microtubule-associated protein 1B : Molecular structure, localization and phosphorylation-dependent expression in developing neurons. Neuron. 3:229 238, 1989

4 ) Hirokawa, N., Shiomura, Y.: Tau proteins : The molecular structure and mode of binding on microtubules. J. Cell. Biol., 107: 1449 1461,1988

5 ) Birider. L. I., Frankfurter. A., Rebhum. L.I., : The distribution of Tau in the mammalian central nervous system. J. Cell. Biol. 101 : 1371 $\sim 1378,1985$

6 ) Vale. R. D., Reese. T. S., Sheetz. M. P. : Identification of a novel force-generating protein, kinesin, involved in micortubule-based motility. Cell. 42: 39〜50, 1985

7 ) Paschal. B. M., Shpetner. H. S., Vallee. R.B.
: MAPIC is a microtubule-activated ATPase which translocates microtubules in vitro and has dynein-like properties. J. Cell. Biol. 105 : 1273 1282,1987

8 ) Shpetner. H.S., Vallee.R.B.: Identification of Dynamin, a novel mechanochemical enzyme that mediates interactions between microtubules. Cell. $59:$ :21 432,1989

9 ) Obar. R. A., Colloins. C. A., Hammarback. J.A., Shpetner. H.S., Vallee. R. B.: Molecular cloning of the microtubule-associated mechanochemical enzyme dynamin reveals homology with a new family of GTP-binding proteins . Nature. $347: 256 \sim 261,1990$

10) Nakata. T., Iwamoto. A., Noda. Y., Takemura. R., Yoshikura. H., Hirokawa. N.: Predominant and developmentally regurated expression of dynamin in neurons. Neuron. $7: 1 \sim 20$. 1991

11) Arnheiter. H., Skuntz. S., Noteborn. M., Chang. S., Meier. E.: Transgenic mice with intracellular immunity to influenza virus. Cell. 62 : 51 61, 1990

12) Rothman. J.H., RAymond. C.K., Gilbert. T., O'hara. P. J., Stevens. H.T.: A putative G TP binding proteins an essential function in the yeast protein sorting. Cell. 61: 1063 1074,1990

13) Yeh. E., Driscoll. R., Coltera. M., Olins. A., Bloom. K.: A dynamin-like protein encoded by the yeast sporulation gene SPO15. Nature. 349 : 713 715, 1991

14) van der Bliek. A.H., Meyerowitz. E.M. : Dynamin-like protein encoded by Drosophila Shibire gene associated with vesicular traffic . Nature., $351:$ :11 414, 1991

15) Chen. M.S., Obar. R.A., Schroeder. C.C., Austin. T. W., Poodry. C. A., Wwamdsworth. S.C., Vallee. R.B.: Multiple forms of dynamin are encoded by shibire, a Drosophila gene involved in endocytosis. Nature., $351: 583 \sim 586$, 1991

16) Towbin. H., Staehelin. H., Gordon. J.: Electrophoreic transfer of proteins from polyacryla- 
mide gels to nitrocellulose sheets procedure and some application. Proc. Acad. Sci. USA., $76: 4350 \sim 4354,1979$

17) Laemmli. U.K. :Cleavage of structural proteins during assembly the head of bacteriophage $\mathrm{T}_{4}$. Nature., $227: 680 \sim 685,1970$

18) Heuser. J.E., Sallpeter. S. R.: Organization of acetylcholine receptors in quick-frozen deepetched, and rotary replicated Torpedo postsynaptic membrane. J. Cell. Biol., 82 : 150 173, 1979
19) Hirokawa. N., Heuser. J.E.: Quick-freeze, deep-etch visualizaion of the cytoskeleton beneath surface differentiation of epithelial cells. J . Cell. Biol., 91 : 339 409, 1981

20) Scaife. R., Margolis. R. L.: Biochemical and immunochemical analysis of rat brain dynamin interaction with microtubules and organelles in vivo and in vitro. J. Cell. Biol. , $111: 3023$ $\sim 3033,1990$

\section{Original paper}

\section{Summary}

The New methods of purification of the rat brain dynamin and its biochemical and ultrastructural analyse of the interaction with microtubules

Dynamin was discovered in calf brain tissue as a nucleotide-sensitive microtubule-binding protein with a molecular mass of 100,000. Cross-linked microtubules into bundles and generated force to slide microtubules in vitro. Therefore, it was thought to be a third mechanochemical enzyme, following MAP $1 \mathrm{C}$ and kinesin. Cloning and sequencing of rat brain dynamin complementary DNA revealed that it contained the consensus sequences of GTP-binding proteins.

Studies on dynamin have been difficult because only a small amount of dynamin could be obtained from the brain. I developed a new purification method of dynamin using a small amount of rat brain tissue. It was a highly efficient and very simple procedure, and enabled a further purification step to obtain pure dynamin. I measured both ATPase and GT Pase activities. In the presence of microtubules, ATPase activity was activated 4 times that in their absence $(\mathrm{Km} \mathrm{1.0)}$. GTPase activity was activated 170 times $(\mathrm{Km} \mathrm{0.07).} \mathrm{This}$ suggests that dynamin plays a greater role as GTPase in vivo than as ATPase. The binding manner of Dynamin to micortubules using a quick-freeze deep-etching technique, revealed that dynamin tightly binds to microtubules and decorates the surface of microtubule helically.

KUNIMI MAEDA, M. D.

Division of Nephrology, Department of Internal Medicine, Juntendo University School of Medicine, Tokyo, Japan 